\title{
粘性減衰を有する 1 質点系の履歴吸収エネルギーに関する考察 \\ STUDY ON HYSTERITIC ENERGY ABSORPTION OF VISCOUSLY DAMPED SINGLE-MASS SYSTEM
}

\author{
三宅辰 哉*, 福知保 長** \\ Tatsuya MIYAKE and Yasunaga FUKUCHI
}

\begin{abstract}
The purpose of this paper is to predict hysteritic absorbed energy of viscously damped single-mass system subjected to earthquake. Bilinear and Slip hysterisis are dealt with. First, based on random vibration theory, a method to get an approximate value of hysteritic absorbed energy when input motions are stationary Gaussian white noise, is studied. By considering a probability distribution of damping dissipate energy per unit time, it is recognized that predicted values become more accurate for wide range of dumping factor and yield share force coefficient, than a result of a past study. Next, based on a past technique to make artificial seismic waves, a deterministic relation between Gaussian white noise and seismic waves, is supposed. And predicted values when input motins are seismic waves, are similarly gotton.
\end{abstract}

\section{keywords : hysteritic absorbed energy, viscous damping, single-mass system, bilinear hysterisis, slip hysterisis, ramdom response, seismic response}

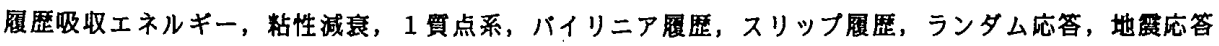

\section{1. 序}

低層鉄骨建築物では間仕切壁など非構造部材の酎震 効果によって、主体構造の水平力分担率は $50 \%$ 程度に低 減され、首ごとの減衰定数は $20 \%$ に達し得ることが実験 的に確認されている1)。また、地震動による入力エネル キーEIの一部は主体構造の塑性化による履歴吸収エネル キーE Eとなり、残りは减衰機構による減衰消費エネルギ 一E $E_{D}$ となる。 $E_{I}$ に対する $E_{S}$ の比率は主体棈造の降代強度 およひ減衰性が高いほど小さくなり、上記のような酎震 効果を有する建築物では $E_{S}<E_{D}$ となることも十分考えら れる。したがって、特に低層鉄骨建築物では合理的な構 造設計を行うために、 $E_{I}$ に対する $E_{s}$ の比率を支配するパ ラメータを明らかにし、その值をできるだけ正確に把握 することが重要な課題である。

洪・田中2) はパイリニア型の復元力特性を有する粘性 減衰 1 筫点系について、入力が定常ホワイトノイスの場 合の $E_{s}$ に関して、減衰定数 $h$ と降伏せん断力係数 $\alpha$ をパ
ラメータとして研究を行っている。しかし、これらの手 法は入力がホワイトノイスであること、および後述のよ うにh、 $\alpha$ が大きくなると予測精度が低下する点に問題 がある。

秋山・加藤 ${ }^{3}$ は、 $E_{I}$ に対する $E_{S}$ の概括的な比率として 次式を提案している。

$$
\frac{E_{S}}{E_{I}}=\frac{1}{(1+3 h+1.2 \sqrt{h})^{2}}
$$

しかし、上式には復元力特性、 $\alpha$ 、および入力の強さな とによる影算が含まれておらず、本論の目的には不十分 である。

本論ではまず、洪・田中らの手法を参考にしてランダ ム振動論に基づき、入力が定常ホワイトノイスの場合の $E_{S}$ の予測手法について検討を行う。そのとき、エネルキ 一入力率の確率分布を考虑して予測精度の向上を図る。 次に、地震動の確率モテルを得るために、定常ホワイト ノイスと地震動の間に、エネルギー入力に関して確定的
$*$ 名古屋工業大学工学部社会開発工学科 大学院生 (日本システム設計)

** 名古屋工業大学工学部社会開発工学科 教授・工博
Graduate Student, Dept. of Architecture, Urban Eng. and Civil Eng., Faculty of Eng., Nagoya Institute of Technology

Prof., Dept. of Architecture, Urban Eng. and Civil Eng., Faculty of Eng., Nagoya Institute of Technology, Dr. Eng. 
な関係があるものとして、既往の人工地震波作成手法に 基つき、実地霞波テータとの比較によりその関係を設定 する。得られた確率モテルを用いて、入力が地震波の場 合の $E_{s}$ の予測手法について㛟討を行う。予湘手法の罗当 性は数值解析によるシミュレーション値との比較により 㛟証する。

\section{1 質点系振動モデル}

本論で扱う 1 質点系振動モテルの变位 $X$ は次の振動方 程式に支哂される。

(線形系) $x^{\prime \prime}+2 h \omega_{0} x^{\prime}+\omega_{0}^{2} x=-y^{\prime \prime}$.

(履歷系 ) $x^{\prime \prime}+2 h \omega_{\circ} x^{\prime}+F\left(x, x^{\prime}\right)=-y^{\prime \prime} \cdots \cdots$

ここで、'は時間に関する微分を表す。 $\omega 。$ は弾性円振 動数、 $h$ は減衰定数、 $y$ 'は入力加速度である。 $F\left(x, x^{\prime}\right)$ は履歷系の復元力関数を表し、図ー 1 のような完全弾塑 性バイリニア型とスリップ型の 2 種䫛を対象とする。 $\alpha$ は降伏せん断力係数、 $g$ は重力加速度、 $\delta_{Y}$ は降伏変位 である。
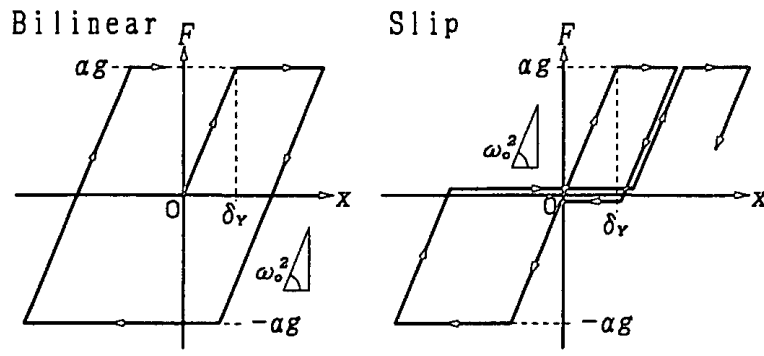

図-1 貿点系の復元力特性

(2)式、（3)式の両辺に変位の增分 $x^{\prime} d t$ を票して加振

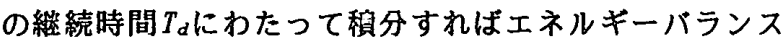
式が得られ、その時間率であるパワーバランス式は次の ようになる。

(線形系)

$$
x^{\prime \prime} X^{\prime}+2 h \omega_{\circ} X^{\prime 2}+\omega_{\circ}^{2} X X^{\prime}=-y^{\prime \prime} X^{\prime}
$$

(履歴系)

$$
x^{\prime \prime} x^{\prime}+2 h \omega_{0} x^{\prime 2}+F\left(x, x^{\prime}\right) x^{\prime}=-y^{\prime \prime} x^{\prime} \cdots
$$

左辺は入力エネルギー $E_{I}$ 、右辺第 1 項は運针エネルギー

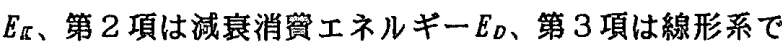
は弾性ポテンシャルエネルギー $E_{P}$ 、履歷系では履䇥吸收 エネルギーE $E_{S}$ と $E_{P}$ の和の時間繁を表す。

入力加速度 $y$ "として表－1に示す実地震波の他、次式 で得られるパワースペクトル密度 $S$ 。、平均値 0 のガウス 型ホワイトノイズ少を用いる。

$$
y^{\prime \prime}(t)=\sum_{k=1}^{N}\left(a_{k} \cos \omega_{k} t+b_{k} \sin \omega_{k} t\right) \cdots \cdots
$$

ここで、䌉続時間を $T_{d}$ 、計算する時間の刻みをd,として

$$
N=T_{d} / d_{t}
$$

$$
\omega_{k}=\pi k / T_{d}
$$

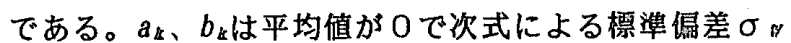

\begin{tabular}{|c|c|c|c|c|c|}
\hline No & Hade & Date & $\begin{array}{c}\text { Peak Acc. } \\
(\mathrm{gal})\end{array}$ & $\begin{array}{l}\text { PEDax } \\
\text { (c口/s) }\end{array}$ & $\begin{array}{c}\text { Data length } \\
\text { (s) }\end{array}$ \\
\hline 1 & E1 Centro,NS & \multirow{2}{*}{ Hay 18,1840} & 341.4 & 133.6 & \multirow{8}{*}{20} \\
\hline 2 & E1 Centro, EH & & 210.1 & 99.7 & \\
\hline 3 & Taft, HS & \multirow{2}{*}{ Jul 21,1952 } & 152.7 & 73.9 & \\
\hline 4 & Taft,EH & & 175.9 & 69.0 & \\
\hline 5 & Hachinohe,NS & \multirow{2}{*}{ Hay 16,1968 . } & 225.0 & 94.6 & \\
\hline 6 & Hachinohe, EH & & 182.9 & 156.5 & \\
\hline 7 & TH030-1FL, NS & \multirow{2}{*}{ Jun 12,1978} & 258.2 & 276.1 & \\
\hline 8 & TH030-1FL,EH & & 202.7 & 163.1 & \\
\hline 9 & Tokyo101,NS & Feb 14,1956 & 74.0 & 24.7 & \multirow{4}{*}{10} \\
\hline 10 & Senda i 501 ,NS & \multirow{2}{*}{30,1862} & 57.5 & 17.9 & \\
\hline 11 & Senda i $501, \mathrm{EH}$ & & 47.5 & 16.2 & \\
\hline 12 & 0saka205, EH & Har 27,1963 & 25.0 & 9.9 & \\
\hline
\end{tabular}
のガウス確率変数で、すべて互いに独立である。

$\sigma_{p}=2 \pi S_{o} / T_{d}$

表一 1 検討に用いた地霞波

3。ラン㞤振動論による履歴吸陨エネルギ一是の予測 3-1 娍衰線形系のランダム応答 ${ }^{5)}$

隇衰線形 1 貿点系にパワースペクトル密度 $S$ 。、平均值 ○のガウス型ホワイトノイズが $t=0$ で静止の状態から 突然作用する場合の非定常応答において、応答変位 $x$ の 2 垂平均 $V_{x}$ は、

$$
\begin{gathered}
V_{x}=\frac{\pi S_{0}}{2 h \omega_{0}^{3}}\left\{1-\left(1+2 \varepsilon^{2} \sin ^{2} \omega^{\prime} t\right.\right. \\
\left.\left.+\varepsilon \sin 2 \omega^{\prime} t\right) \exp \left(-2 h \omega_{\circ} t\right)\right\} \\
\text { ここで、 } \omega^{\prime}=\omega_{\circ} \sqrt{1-h^{2}} \\
\varepsilon=h / \sqrt{1-h^{2}}
\end{gathered}
$$

$\sin \omega^{\prime} t$ 変動項を無視すると近似的に、

$$
V_{x}=\frac{\pi S_{0}}{2 h \omega_{0}^{3}}\left\{1-\exp \left(-2 h \omega_{\circ} t\right)\right\}
$$

応答速度 $x^{\prime}$ の 2 垂平均 $V_{x} \cdot$ は、

$$
V_{x},=\omega_{0}^{2} V_{x}=\frac{\pi S_{0}}{2 h \omega_{0}}\left\{1-\exp \left(-2 h \omega_{0} t\right)\right\} \cdots
$$

定常応答状怨では $t \rightarrow \infty$ として、

$$
V_{x} \cdot=\frac{\pi S_{0}}{2 h \omega_{0}}
$$

入力がガウス分布であれば線形系の応答 $X$ はガウス分 布の独帯域過程となり、その包絡線の確率分布、すなわ ち $x$ の振幅 $B_{x}$ の確率分布 $p\left(B_{x}\right)$ は次式のレーリー分布に なる。

$$
p\left(B_{x}\right)=\frac{B_{x}}{V_{x}} \exp \left(-B_{x}^{2} / 2 V_{x}\right)
$$

$B_{x}$ の 2 垂平均 $E\left[B_{x}^{2}\right]$ は次のようになる。

$$
E\left[B_{x}^{2}\right]=2 V_{x}
$$

また、全入力エネルギーの期待值 $E\left[E_{I}\right]$ は、

$$
E\left[E_{I}\right]=\pi S_{0} t
$$

である。応答速度振稫の 2 妻平均 $E\left[B_{x}, 2\right]$ は(15)式によ り $2 V_{x} \cdot$ であるので、振動エネルギーの期待値 $E\left[E_{V}\right]$ は、 
$E\left[E_{v}\right]=E\left[B_{x}, 2\right] / 2=V_{x}$.

減衰消費エネルキーの期待値 $E\left[E_{D}\right]$ は単位時間当たり $2 h$ • $\omega$ 。Vx

$$
\begin{aligned}
E\left[E_{D}\right] & =\pi S_{0} \int_{0}^{t}\left\{1-\exp \left(-2 h \omega_{0} \tau\right)\right\} \mathrm{d} \tau \\
& =\pi S_{0} t-\frac{\pi S_{0}}{2 h \omega_{0}}\left\{1-\exp \left(-2 h \omega_{0} t\right)\right\} \\
& =E\left[E_{I}\right]-E\left[E_{V}\right] \cdots \cdots \cdots \cdots \cdots \cdots \cdots \cdots \cdots \cdots
\end{aligned}
$$

となる。

3-2 塑性化に寄与寸るエネルギー

線形系における減衰によるエネルギー消費率 $E_{D}$ 'は次 のようになる。

$$
E_{0}{ }^{\prime}=2 h \omega_{0} X^{\prime 2}
$$

ここでxedを次のように定義する。

$$
x_{e d}=\sqrt{E_{0}{ }^{\prime}}=\sqrt{2 h \omega_{0}} \cdot x^{\prime}
$$

$x_{e d}$ の 2 乗平均 $V_{e d}$ と、その振幅 $B_{e d}$ の確率分布 $p\left(B_{e d}\right)$ は次のようになる。

$$
\begin{aligned}
& V_{e d}=2 h \omega_{0} V_{x} . \\
& \quad=\pi S_{0}\left\{1-\exp \left(-2 h \omega_{0} t\right)\right\} \cdots \\
& p\left(B_{e d}\right)=\frac{B_{e d}}{V_{e d}} \exp \left(-B_{e d} / 2 V_{e d}\right)
\end{aligned}
$$

$E_{D}{ }^{\prime}=X_{e d}{ }^{2}$ であるので、 $V_{e d}$ は $E_{D}{ }^{\prime}$ の期待値 $E\left[E_{D}{ }^{\prime}\right]$ であ り、 $B_{e d}$ と $B_{e d 2}$ の確蜜分布は同一であるので、 $p\left(B_{e d}\right)$ は $E_{D}^{\prime}$ の極大值の確害分布を示す。

この $p\left(B_{\text {ed }}\right)$ を用いて履歴系の塑性化に寄与するエネル キー量を求める。このとき(21)式の指数関数部か $E\left[E_{V}\right]$ の增加事を表すが、履歴系では一般に弾塑性応答により 見かけの減言定数が增大し、線形系に比へ振動エネルキ 一量が減少することを考虑して、安全側に $E\left[E_{v}\right]=0$ と

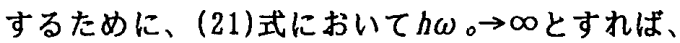

$V_{e d}=\pi S_{0}$

となる。すなわち、履歴系の弹望性応答に対して等価な 線形系が存在し、その振幅がレーリー分布に従い、入力 エネルギーが即時に減衰消費されるものとすれは、V Ved、 $p\left(B_{\text {ed }}\right)$ は塑性化の度合いに関わらず、入力波のパワース ペクトル密度 $S$ 。のみによって定まる。なお、 $h \omega 。 \rightarrow$ と した場合、系に振動は生じないが、これは(21)式におい $\tau E\left[E_{V}\right]=0$ を考虑するためのみの処置である。

履歴系では応答変位 $x$ の振幅 $B_{x}$ が $\delta y$ 以下であれば系 に望性化は生しない。 $B_{x}=\delta y$ のときの応答速度振幅 $B_{Y}$ およびエネルギー消費率 $E_{Y}^{\prime}$ は、

$$
\begin{aligned}
& B_{Y}=\omega_{\circ} \delta_{Y}=g \alpha / \omega_{\circ} \cdots \cdots \cdots \cdots \cdots \cdots \cdots \\
& E_{Y}{ }^{\prime}=2 h \omega_{\circ} B_{Y}{ }^{2} \cdots \cdots \cdots \cdots \cdots \cdots \cdots \cdots \cdots
\end{aligned}
$$

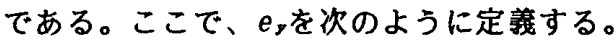

$$
e_{y}=\sqrt{E_{Y}}=\sqrt{2 h \omega_{0}} \cdot B_{Y}
$$

$(20)$ 式の $x_{e d}$ の振幅 $B_{e d}$ がこの $e_{y}$ 以上のとき系に望性化か 生しる。時刻 $t$ において、 $B_{e d} \geqq e_{s}$ を渵足する $x_{e d}$ による 单位時間当たりの減衰消費エネルギーの期待值 $E\left[e_{0}(t)\right]$
は、

$$
E\left[e_{0}(t)\right]=\int_{0}^{\infty}(1 / 2) B^{2} p(B) d B
$$

その入力時間の期待値 $E\left[t_{0}(t)\right]$ は、

$$
E\left[t_{0}(t)\right]=\int_{o,}^{\infty} p(B) d B
$$

$p(B)$ に(22)式を用いれば(27)式、(28)式は、

$$
\begin{aligned}
& E\left[e_{0}(t)\right]=\left(h \omega_{0} B Y_{Y}{ }^{2}+V_{e d}\right) \exp \left(-h \omega_{0} B r^{2} / V_{e d}\right) \\
& E\left[t_{0}(t)\right]=\exp \left(-h \omega_{\circ} B_{Y}{ }^{2} / V_{e d}\right) \cdots \cdots \cdots \cdots \cdots
\end{aligned}
$$

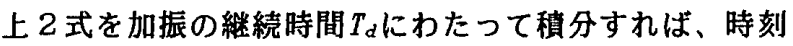
$0 \sim T_{d}$ 間の塑性化に寄与するエネルギー量 $E_{H}$ とその入力 時間 $T_{H}$ の期待值が得られる。

$$
\begin{aligned}
& E\left[E_{H}\right]=\int_{0}^{T_{0}}\left(h \omega_{\odot} B_{Y}{ }^{2}+V_{e d}\right) \exp \left(-h \omega_{o} B_{Y}{ }^{2} / V_{e d}\right) d t \\
& E\left[T_{H}\right]=\int_{0}^{T_{0}} \exp \left(-h \omega_{0} B_{Y}{ }^{2} / V_{e d}\right) d t \ldots \ldots \ldots \ldots \ldots
\end{aligned}
$$

Vedに(23)式を用いれば(31)式、(32)式は、

$$
\begin{aligned}
& E\left[E_{H}\right]=T_{d}\left(h \omega_{\circ} B Y^{2}+\pi S_{o}\right) \exp \left(-h \omega_{\circ} B Y^{2} / \pi S_{0}\right) \\
& E\left[T_{H}\right]=T_{d} \exp \left(-h \omega_{\circ} B_{Y}^{2} / \pi S_{0}\right) \cdots \cdots \cdots \cdots \cdots
\end{aligned}
$$

3-3 履歴吸収エネルギー

入力y"が正弦波であるときの共振状態を考え、四一 のように共振応答変位を、

$$
x=r \cos \omega_{r} t
$$

とし、これを(4)式のパワーバランス式に代入する。

$$
\left(-r \omega_{r}^{2} \cos \omega_{r} t\right)\left(-r \omega_{r} \sin \omega_{r} t\right)
$$$$
+2 h \omega_{0}\left(-r \omega_{r} \sin \omega_{r} t\right)^{2}
$$$$
+F\left(r \cos \omega_{r} t, t\right)\left(-r \omega_{r} \sin \omega_{r} t\right)
$$$$
=-f \sin \omega_{r} t\left(-r \omega_{r} \sin \omega_{r} t\right)
$$
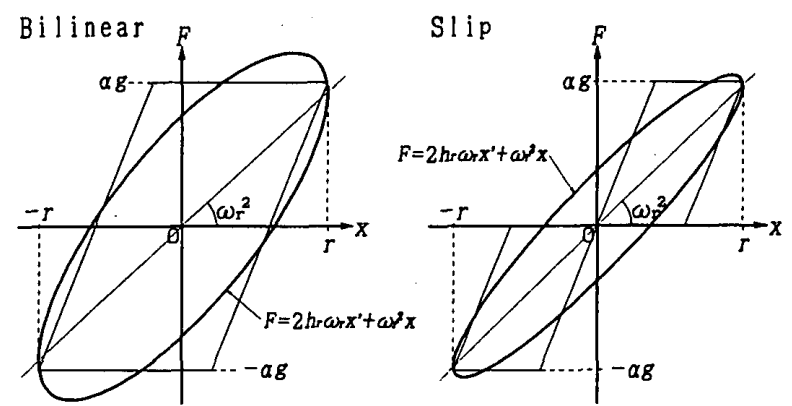

図ー2 共振状態における等価線形モテル

上式を時刻 0 から $2 \pi / \omega_{r}$ まで樌分し、 $2 \pi / \omega_{r}$ で割る。 パイリニア型

$$
h \omega_{0} \omega_{r}^{2} r^{2}+\frac{2 \omega_{r}}{\pi}\left(r-\delta_{r}\right) g \alpha=\bar{E}_{H}
$$

スリップ型

$$
h \omega_{\circ} \omega_{r}^{2} r^{2}+\frac{\omega_{r}}{\pi}\left(r-\delta_{r}\right) g \alpha=\bar{E}_{H}
$$

上式の右辺 $\bar{E}_{H}$ は平均エネルキー入力率であり、次式とす 
る。

$\bar{E}_{H}=E\left[E_{H}\right] / E\left[T_{H}\right]$

最小自乗法による等価線形化手法 ${ }^{5}$ によれば、共振状 態における応答変位振幅 $r$ が与えられたとき、等価円振 動數 $\omega$ ，と等価減衰定致 $h$ ，は次のようになる。

$$
\begin{gathered}
\omega_{r}^{2}=C \omega o^{2} \ldots \ldots \\
h_{r}=\frac{S}{2 C}+\frac{h}{\sqrt{C}}
\end{gathered}
$$

ここで、C,S は次式による。

パイリニア型

$$
\begin{aligned}
& C=\frac{1}{\pi}\left(\theta_{1}-\frac{1}{2} \sin 2 \theta_{1}\right) \\
& S=\frac{1}{\pi} \sin ^{2} \theta_{1} \ldots \ldots \ldots \ldots
\end{aligned}
$$

ただし、 $\theta_{1}=\cos ^{-1}\left(1-2 \frac{\delta Y}{r}\right), r>\delta Y$ スリップ型

$$
\begin{aligned}
& C= \frac{1}{\pi}\left\{\theta_{1}-\theta_{2}+\pi / 2\right. \\
&\left.-\frac{1}{2}\left(\sin 2 \theta_{1}-\sin 2 \theta_{2}\right)\right\} \cdots \cdots \cdots \cdots \\
& S= \frac{1}{\pi}\left(\sin ^{2} \theta_{1}+\sin ^{2} \theta_{2}-1\right) \cdots \cdots \cdots \\
& \text { ただし、 } \theta_{1}=\cos ^{-1}\left(1-\frac{\delta_{Y}}{r}\right) \\
& \quad \theta_{2}=\cos ^{-1}\left(\frac{\delta_{Y}}{r}\right), r>\delta_{Y}
\end{aligned}
$$

(37)式あるいは(38)式と、（40)式を通立して解けば $r$ 、 $\omega$ ，が求められ、履歷吸収エネルギーの期待値 $E\left[E_{s}\right]$ は次 のようになる。

$$
\begin{aligned}
& \text { パイリニア型 } \\
& E\left[E_{s}\right]=\frac{2 \omega_{r}}{\pi}\left(r-\delta_{r}\right) g \alpha E\left[T_{H}\right]
\end{aligned}
$$

スリップ型

$$
E\left[E_{S}\right]=\frac{\omega_{r}}{\pi}\left(r-\delta_{Y}\right) g \alpha E\left[T_{H}\right]
$$

また、スリップ型については系の等価な弾性判性が系の 望性化に佯い低下するので、次のように段階的に解析を 行う。

\section{第1ステッフ}

(1)演算を行い、 $\Gamma_{1} 、 \omega_{r 1}$ を求める。 (2) (47)式により $E\left[E_{s}\right]$ を計算する。

(3)経過時間 $T_{p}=2 \pi / \omega_{r 1}$ とする。

第 2 ステップ以降

(4) $\omega_{0 t}=\omega_{0} \sqrt{\delta Y / r_{I-1}}, h_{t}=h \sqrt{r_{t-1} / \delta r}$

$\delta_{Y t}=r_{t-1}$ として $\bar{E}_{H}$ を更新する。

(5)演算を行い、 $r_{1} 、 \omega_{r}$ を求める。

(6) (47) 式により履歴吸収エネルキーの增分を計算し、

$E\left[E_{s}\right]$ に加算する。

(7)経過時間 $T_{r}$ に $T_{r}=2 \pi / \omega_{r}$ を加算する。

以降、 $T_{P}$ が $E\left[T_{H}\right]$ に達するまで(4)〜 (7を綎り返す。ただ
し、最終ステップの履歴吸収エネルギーの增分は、(47) 式で求められる值に $\left(T_{P}-E\left[T_{H}\right]\right) / T_{r}$ を垂じ。

3-4シミュレーションによる検討

以上のように求められる解析值の妥当性を模証するた めに、モンテカルロ・シミュレーションによる数値実駼 を行った。 $S_{o}=300 \mathrm{~cm}^{2} / \mathrm{s}^{3} 、 T_{d}=10 \mathrm{~s} 、 d_{t}=0.01 \mathrm{~s} と し て(6)$ 式により作成した 500個のガウス型ホワイトノイズサン プルを用いて応答計算を行い、結果を統計的に処理し、 解析值と比斡する。比較の対象は全入力エネルギーに対 する履歷吸收エネルギーの比率

$\mu=E\left[E_{s} / E_{o}\right]$

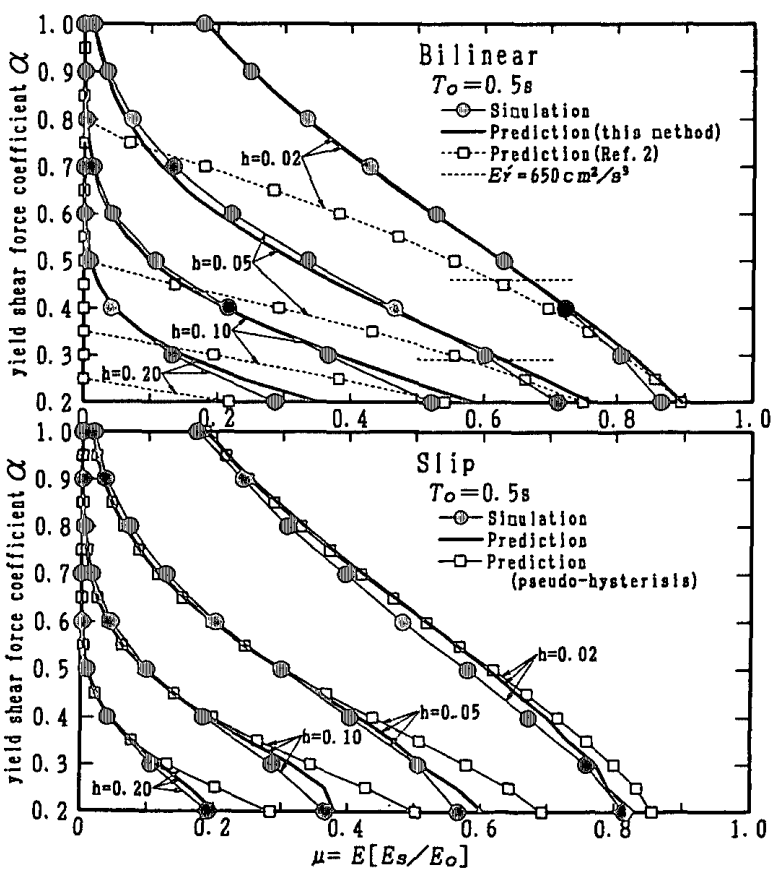

図ー３ ガウス型W Nによる履歴吸収エネルギー

比較結果を図ー 3 に示す。バイリニア型では $\alpha$ が小さい 場合、解析值は若干過大評価となるが全体的には良く一 致している。スリップ型では 3-3項に示す段階的解析值

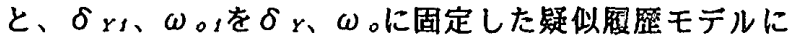
よる解析值を示したが、段階的解析はバイリニア型と同 様にシミュレーション值と良く一致している。疑似履櫪 モテルによる解析犆は $\alpha$ が小さい場合やや過大䛨価とな る。

文献2)では(37)式、(38)式中の平均エネルキー入力率 $\bar{E}_{H}$ を定常ホワイトノイスの平均エネルギー入力率 $\pi S_{0}$ と し、(46)式、(47)式中の入力時間の期待值 $E\left[T_{H}\right]$ を加振 の全綌続時間 $T_{d}$ として、3-3項と同様の手法によってパ イリニア型の履歷吸収エネルギーの期待値 $E\left[E_{S}\right]$ を求め ている。その結果を図ー3に併記したか、、ネルギー入 力波の振幅の確率分布が考應されていないため、系の降 伏エネルギー消留率 $E_{Y}{ }^{\prime}$ が大きい $\left(E_{Y}{ }^{\prime}>650 \mathrm{~cm}^{2} / \mathrm{s}^{3}\right.$ 程度) 場合は予測踴度が低下する。 


\section{4、実地震波による覆歴吸収エネルギ一量の予測 \\ 4-1 地震動の確率モデル}

地震動の確率モテルとして図ー4のように、確定形状 関数 (包絡線関数) $a(t)$ によって非定常化されたガウス型 ホワイトノイス(擬定常ホワイトノイス)を、地盤特性を 表現する確定線形フイルターF(i $i \omega)$ に通したランタム過 程を用いることが良く行われる。本論でもこの手法に従 い、ガウス型ホワイトノイスと地震動は $a(t) 、 F(i \omega)$ を 介在させることで関係づけられるものとする。

\begin{tabular}{|c|c|}
\hline \multicolumn{2}{|c|}{ ガウス型ホワイトノイス $n(t)$} \\
\hline 1 & $t$ \\
\hline$n^{\prime}(t)=a(t) n(t)$ & $n(t)=n^{\prime}(t) / a(t)$ \\
\hline+ & $\uparrow$ \\
\hline \multicolumn{2}{|c|}{ 塚定常ホワイトノイス $n^{\prime}(t)$} \\
\hline 1 & $\uparrow$ \\
\hline$N^{\prime}(i \omega)=(B)\left[n^{\prime}(t)\right]$ & $n^{\prime}(t)=\left(\mathrm{B}^{-1}\left[N^{\prime}(i \omega)\right]\right.$ \\
\hline$\gamma^{\prime \prime}(i \omega)=F(i \omega) N^{\prime}(i \omega)$ & $N^{\prime}(i \omega)=Y^{\prime \prime}(i \omega) / F(i \omega$ \\
\hline$y^{\prime \prime}(t)=(\mathbb{B})^{-1}\left[Y^{\prime \prime}(i \omega)\right]$ & $Y^{\prime \prime}(j \omega)=\left(\hat{B}\left[y^{\prime \prime}(t)\right]\right.$ \\
\hline 1 & $\uparrow$ \\
\hline 地震波 $y^{\prime \prime}(t)$ & \\
\hline
\end{tabular}

ただし、の：フーリエ変換、 $i$ : 虚数単位 (B) $-1:$ 逆フーリエ変換

困ー4 地震動の確率モテル

\section{4-2 地震動による入カエネルギーの期待値}

地震入カエネルギーは周波数領域において次のように 表現される6)。

$$
E_{I}=\int_{-\infty}^{\infty} H(\omega)\left|Y^{\prime \prime}(i \omega)\right|^{2} d \omega
$$

\section{ここで、||:複素数の絶対值}

上式中の $W(\omega)$ は次式の粘性減衰弾性 1 賈点系のエネキ ーアドミッタンスであり、速度伝達関数の実数部に $1 / 2 \pi$ を乗じたものである。

$$
W(\omega)=\frac{h \omega_{0} \omega^{2}}{\pi\left\{\left(\omega_{0}^{2}-\omega^{2}\right)^{2}+4 h \omega_{0}^{2} \omega^{2}\right\}}
$$

期待値は次のようになる。

$$
\begin{aligned}
& E\left[E_{I}\right]=\int_{-\infty}^{\infty} H(\omega) E\left[\left|Y^{\prime \prime}(i \omega)\right|^{2}\right] d \omega \cdots \cdots \cdots \cdots \\
& \text { ここで、 } \\
& E\left[\left|Y^{\prime \prime}(i \omega)\right|^{2}\right]=|F(i \omega)|^{2} E\left[\left|N^{\prime}(i \omega)\right|^{2}\right] \\
& =|F(i \omega)|^{2} \int_{-\infty}^{\infty} \int_{-\infty}^{\infty} a\left(t_{t}\right) a\left(t_{2}\right) \exp \left\{i \omega\left(t_{1}-t_{2}\right)\right\} \\
& \quad \cdot E\left[n\left(t_{1}\right) n\left(t_{2}\right)\right] d t_{1} d t_{2} \cdots
\end{aligned}
$$

$n(\tau)$ はホワイトノイスであるから

$$
\begin{aligned}
& E\left[n\left(\tau_{1}\right) n\left(\tau_{2}\right)\right]=2 \pi S_{0} \delta\left(\tau_{1}-\tau_{2}\right) \cdots \cdots(53)
\end{aligned}
$$

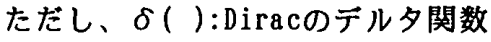

(53)式を(52)式に代入して、

$$
\begin{aligned}
& E\left[\left|Y^{\prime \prime}(i \omega)\right|^{2}\right]=2 \pi S_{0}|F(i \omega)|^{2} A \cdots \\
& \text { ただし、 } A=\int_{0}^{t} a(\tau)^{2} \mathrm{~d} \tau
\end{aligned}
$$

であるので、

$$
E\left[E_{I}\right]=2 \pi S_{0} A \int_{-\infty}^{\infty}|F(i \omega)|^{2} W(\omega) d \omega
$$

また、 $N(\omega)$ のバンド幅が狭く、 $\omega 。$ 近㒀で $|F(i \omega)|^{2}$ が ゆるやかに変化している場合には、次式のような狭帯域 近似が可能である。

$E\left[E_{l}\right] \simeq \pi S_{0} A\left|F\left(i \omega_{0}\right)\right|^{2}$

4-3 挻定常ホワイトノイズによる履歴吸収エネルギー

パワースペクトル密度S。のガウス型ホワイトノイスに 確定形状関数 $a(t)$ を乗した擬定常ホワイトノイスによる 入カエネルギー量 $E_{W}(t)$ の期待値は、(56)式において $|F(i \omega)|^{2}=1$ として、

$$
E\left[E_{N}(t)\right]=\pi S_{0} A
$$

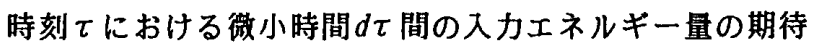
値は、

$$
E\left[e_{w}(\tau)\right]=\pi S_{o} a(\tau)^{2} d \tau
$$

この入力によって生しる自由振動の時刻ににおる 2 乗平 均速度 $v_{x} \cdot(t)$ の期待値は、

$$
E\left[V_{x},(t)\right]=E\left[e_{v}(\tau)\right] \exp \left\{-2 \mathrm{~h} \omega_{0}(t-\tau)\right\}
$$$$
=\pi S_{o} a(\tau)^{2} \exp \left\{-2 h \omega_{0}(t-\tau)\right\} d \tau \quad \cdots
$$

これを時刻 0 から $t$ まで重ね合わせれは、擬定常ホワイ トノイスによる 2 乗平均応答速度が得られる。

$$
V_{x}=\pi S_{0} \int_{0}^{1} a(\tau)^{2} \cdot \exp \{-2 h \omega(t-\tau)\} d \tau \cdots
$$

图ー5および次式に示す確定形状関数を用いれば、

$$
a(t)=\mathrm{b} \cdot t \cdot \exp (-\mathrm{c} \cdot t)
$$

$V_{x} \cdot$ は次のようになる。

$$
\begin{gathered}
V_{x}=\frac{\pi S_{o} b^{2}}{H^{3}}\left\{\left(H^{2} t^{2}-2 H t+2\right) \exp (-2 \mathrm{c} \cdot t)\right. \\
\left.-2 \exp \left(-2 h \omega_{\circ} t\right)\right\} \cdots \cdots \\
\text { ただし、 } H=2 h \omega_{\circ}-2 \mathrm{c}
\end{gathered}
$$

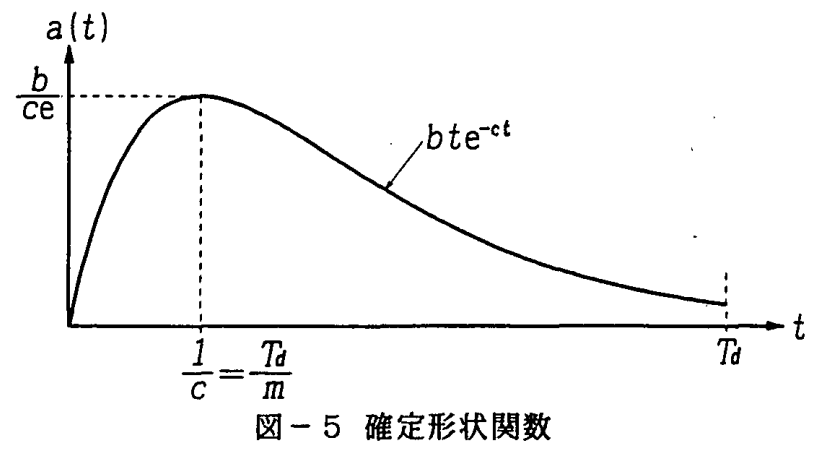

上式に $2 h \omega$ 。を乗し (21)式と同様に $h \omega 。 \rightarrow \infty$ とすれば、 (23)式に相当する趣定常ホワイトノイスによるV $V_{\text {ed }}$ は次 式となる。 
$V_{e d}=\pi S_{o} a(t)^{2}$

上式を(31)式、(32)式に用いれば擬定常ホワイトノイス による、望性化に笴与するエネルギー蛋の期待值 $E\left[E_{H}\right]$ とその入力時間の期待值 $E\left[T_{H}\right]$ が得られる。たたし、こ の場合(31)式、(32)式の指数関数の指敨部にさらに指数 関数が含まれ、(33)式、(34)式のように展開することが

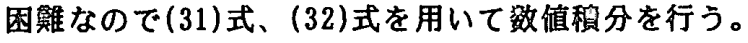

このようにして得られる $E\left[E_{H}\right] 、 E\left[T_{H}\right]$ および $E\left[E_{H}\right] の$ 平均入力辈 $\bar{E}_{H}=E\left[E_{H}\right] / E\left[T_{H}\right]$ を3-3項中の各式に用いれば

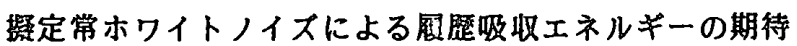
値 $E\left[E_{s}\right]$ が求められる。

また、（57)式において $A=T_{d}$ となるようにb,c を瀷べ ば、 $O \sim T_{d}$ 間の擬定常ホワイトノイズによる入力エネル ギ一星の期待值は、ガウス型ホワイトノイズによるそれ と等しくなる。このとき $b, c$ は次のようになる。

$$
c=\frac{\mathbb{m}}{T_{d}}
$$

として

$$
b=\frac{1}{T_{d}} \cdot \sqrt{\frac{4 m^{3}}{1-2 m^{2}\left(1-\frac{1}{m}+\frac{1}{2 m^{2}}\right) \exp (-2 m)}} \ldots
$$

以上のように求められる解析値の罗当性を梚証するた めに、3-4項と同權にモンテカルロ・シミュレーション による数値実䮲を行った。 $S_{o}=300 \mathrm{~cm}^{2} / \mathrm{s}^{3}, T_{d}=10 \mathrm{~s}$ として (6)式により求めたカウス型ホワイトノイズに、(64)式 およひ、(65)式において明4(c=0.4,b=1.6068) とした確 定形状関数を乗して作成した 160個の擬定常ホワイトノ イスサンプルを用いて応答計算を行い、結果を統計的に 処理し、解析値と比皎する。比较の対像は (48)式による

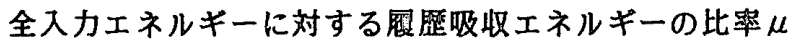

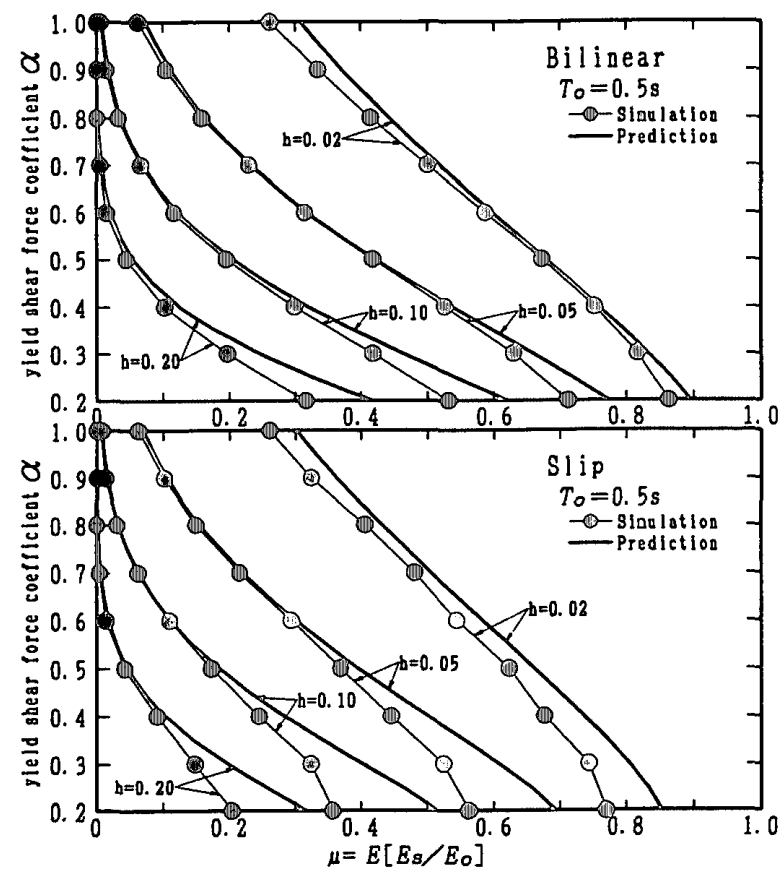

図ー6 擬定常W Nによる風歷吸收エネルギー
である。

比較結果を図一 6 に示す。スリップ型の解析值は $\delta$ と、

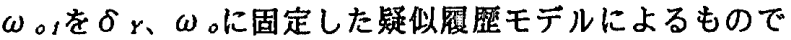
ある。図ー3の定常ホワイトノイスの場合に較べ、予测 蹓度は若干劣るが、䌊して良く一致している。

4-4 確定形状関数の選定

表一 1 に示す No. 1〜8の地霞波を用いて娍衰線形 1 貿点系の応答解析を行い、(19)式による淢衰消貿エネル キ一率 $E_{d}$ 'の時刻歷波形を求める。これを始点 $(t=0)$ 、 終点 $\left(t=T_{d}\right)$ および各極小点で分劉し、分割された各区間

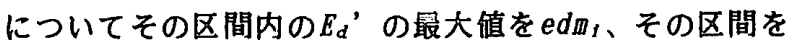
時間について䄯分して得られるエネルギー墨を ed、そ の区間の経過時間を $t d$ ，とする。ed甲が(25)式の降代工

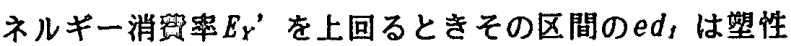

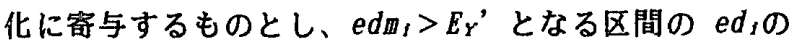
合計を塑性化に答与するエネルキー $E_{H 、} t d_{1}$ の合計を $E_{H}$ が入力される時間 $T_{H}$ とする。これらを擬定常ホワイトノ イスによる $E\left[E_{H}\right] 、 E\left[T_{H}\right]$ と比較し、両者が等しくなるよ うな確定形状関致 $a(t)$ を定める。

各地露波は系の固有周期 $T$ 。に応じて、次式による入力 エネルキーーE $E_{I}\left(T_{0}\right)$ の等価速度 $V_{E}\left(T_{0}\right)$ が、

$V_{E}\left(T_{0}\right)=\sqrt{2 E_{I}\left(T_{0}\right)}$

200kineとなるように規準化し、地盤特性フィルターの 影響を排除する。このとき、E[ $\left.E_{H}\right]$ およひ $E\left[T_{H}\right]$ の算出に 際して用いる(63)式中の $\pi S_{0}$ は、 $V_{E}\left(T_{0}\right)^{2} /\left(2 T_{d}\right)=1000$ $\mathrm{cm}^{2} / \mathrm{s}^{3}$ となる。また、(19)式中の $h$ は振動エネルギーを できるだけ小さくするために、十分大きな值として 0.2 とする。
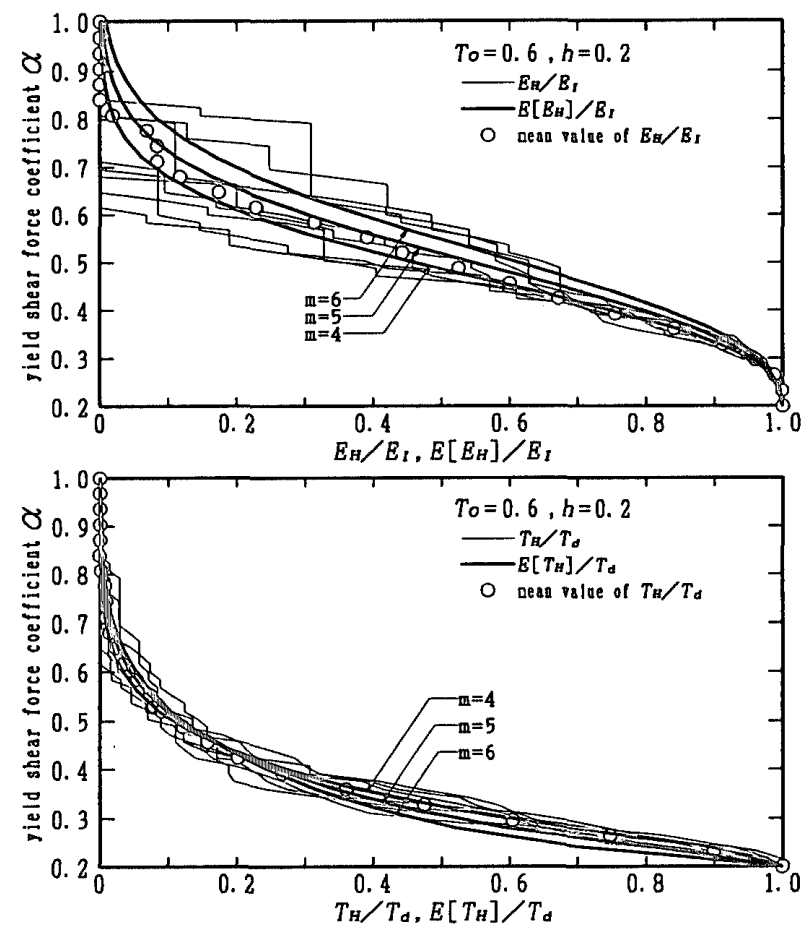

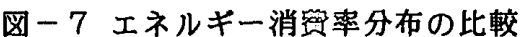


比較結果を図一 7 に示した。 $E_{H} 、 E\left[E_{H}\right]$ は全入力エネ ルギーE $E_{I}\left(20000 \mathrm{~cm}^{2} / \mathrm{s}^{2}\right)$ に対する比率、 $T_{H} 、 E\left[T_{H}\right]$ は全継 続時間 $T_{d}(20 \mathrm{~s})$ に対する比率で表示してある。同図によ れば、(64)式、(65)式で $\mathbb{m}=4$ ～5とした擬定常ホワイトノ イスによるE[E $E$ 扩よひ $E\left[T_{H}\right]$ が8種類の地震波のE $E_{H}$ お よび $T_{H}$ の平均值にほほ一致し、 $m=6$ とすれば $E\left[E_{H}\right]$ が $E_{H}$ の上限值にほほ一致することがわかる。

\section{4-5 地震波による入力エネルギーの変動係数}

地震波が図ー4のようにガウス型ホワイトノイスと関 係づけられるとすれば、地霞波のフーリエ 2 乗振幅スペ クトルは (54)式の期待值を中心として分布しているとみ なせるので、フーリエ 2 乗振幅スペクトルを平滑化した ものが近似的にその期待值になると考えられる。したが って、(54)式に相当する地震波のうーリエ 2 乗振幅スペ クトルの期待值 $E\left[\left|Y "\left(i \omega_{0}\right)\right|^{2}\right]$ を困ー 8 に示すように、 フーリエ 2 乗振幅スペクトルをパンド幅 $1 \mathrm{~Hz}$ HParzenウ インドウによって平滑化したものとする。これを(51)式 に代入して数值䅡分を行えば、图ー9のように地霞波に よる入力エネルギーの期待值 $E\left[E_{I}(\omega\right.$ 。 $\left.)\right]$ が得られる。

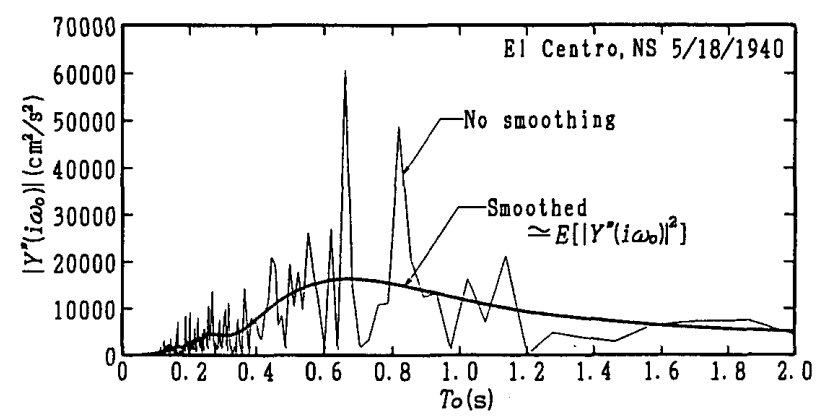

図-8 地霞波の $E\left[\left|Y^{\prime \prime}\left(i \omega_{\circ}\right)\right|^{2}\right]$

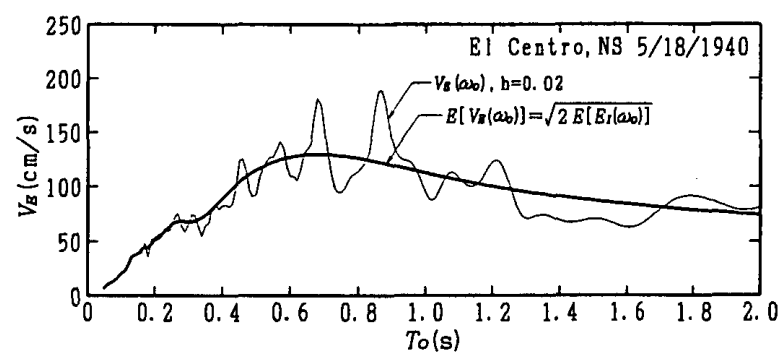

困ー9 地震波による入カエネルギーの期待値

これを用いて、表ー 1 に示す 12 種類の地震波を母集団と したときの、実地霞波による入カエネルギーの変動係数 $\operatorname{CV}\left[E_{I}\left(\omega_{\circ}\right)\right]$ を次のように求める。

$$
\begin{array}{r}
\operatorname{CV}\left[E_{I}\left(\omega_{\circ}\right)\right]=\sqrt{\frac{1}{\mathrm{k}} \sum_{j=1}^{k}\left(\bar{E}_{J}\left(\omega_{\circ}\right)-1\right)^{2}} \ldots \ldots(67) \\
\text { ここで、 } \bar{E} I_{J}\left(\omega_{\circ}\right)=\frac{E_{I J}\left(\omega_{\circ}\right)}{E\left[E_{I I t}\left(\omega_{0}\right)\right]}, \mathrm{k}=12
\end{array}
$$

(61) 式の確定形状関数による擬定常過程の入力エネルギ 一の変動係数の笅密解は次のようになる6)。

$$
\begin{aligned}
& C V_{1}\left(\omega_{0}\right)=\sqrt{\frac{c}{8\left(1-h^{2}\right)}\left[\frac{C_{A}}{C_{B}}+\frac{C_{C}+C_{D}-C_{E}}{C_{F}}\right]} \cdots \\
& \text { ただし、 } C_{A}=8 c^{2}+9 c \omega_{0} h+3 \omega_{\circ}^{2} h^{2} \\
& C_{B}=\left(c+\omega_{0} h\right)^{3} \\
& C_{c}=7 c^{5}\left(1-2 h^{2}\right) \\
& C_{D}=c^{3}\left\{c\left(1-2 h^{2}\right)+\omega_{0} h\right\}\left(c+2 \omega_{\circ} h\right) \\
& C_{E}=\omega_{0} h\left(3 \omega_{0}^{2}+8 c^{2}+6 c \omega_{0} h\right)\left(2 c h+\omega_{0}\right)^{2} \\
& C_{F}=\left(c^{2}+\omega_{0}^{2}+2 c \omega_{0} h\right)^{3}
\end{aligned}
$$

また、ガウス型ホワイトノイスによる定常応答状態にお ける入力エネルギーの分散 $V\left[E_{I}\right]$ は、

$$
V\left[E_{f}\right]=\frac{\pi^{2} S_{o}^{2} t}{h \omega_{0}}
$$

であるので2)、上式および(16)式により定常ホワイトノ イスによる入カエネルギーの変動係数は、

$$
C V_{2}\left(\omega_{0}\right)=\frac{\sqrt{V\left[E_{I}\left(\omega_{0}\right)\right]}}{E\left[E_{I}\left(\omega_{0}\right)\right]}=\frac{1}{\sqrt{\omega_{0} h T_{d}}}
$$

エネルギーを(66)式により、等価速度に換算した場合の $C V\left[E_{I}\left(\omega_{\circ}\right)\right] 、 C V_{1}\left(\omega_{\circ}\right)$ およひ $C V_{2}\left(\omega_{\circ}\right)$ を图一10に示す。 なお、(68)式中の係数 $c$ の值は 4-4項の换討結果から、 (64)式において田 $=4$ として $c=4 / 20=0.2$ とした。本図に

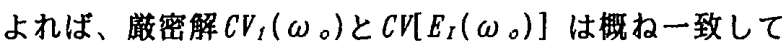

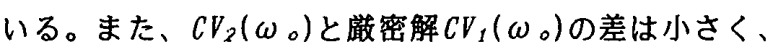
$C V_{2}(\omega$ 。)を実地霞波による入力エネルギーの变動係数と しても実用上の問題はないと言える。

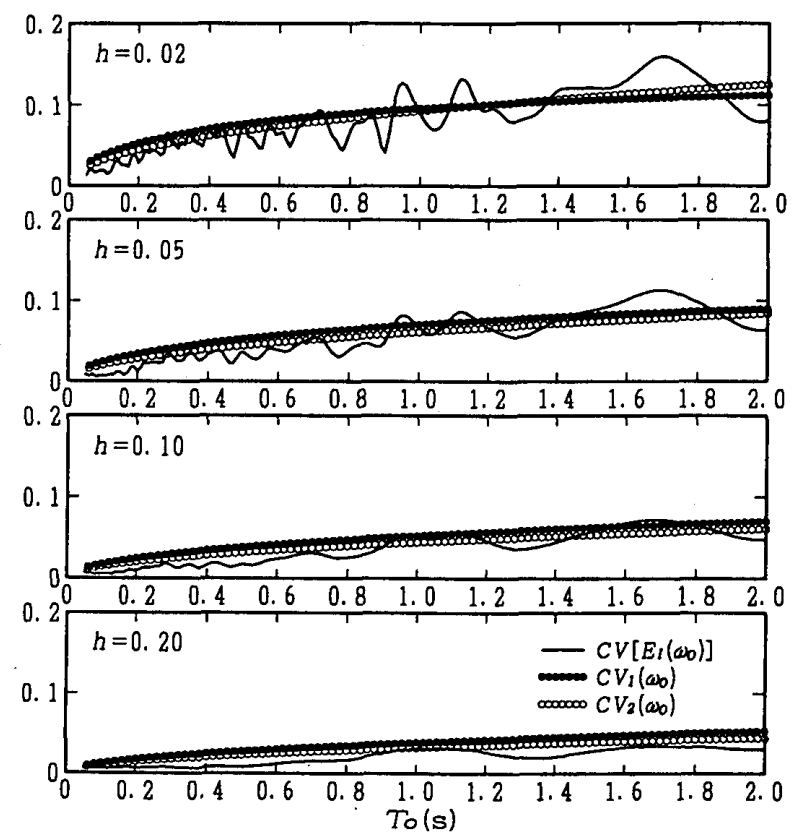

図ー10 地震波による入力エネルキーの変動係数

4-6 地盤特性フィルターの伝達関数の選定

地震動による単位質量当たりの全入力エネルキー屋 $E_{I}$ は系の固有周期 $T$ 。のみに低存し、系の強度および復元力 特性に影響されない安定した量である。 $E_{I}$ を(66)式で定 義される等価速度 $V_{E}$ に換算した場合、 $V_{E}$ と固有周期 $T_{\text {。 }}$ 
の関係、すなわちエネルギースペクトルは図ー11に示す ように長周期領域で一定値 $V_{E O}$ となるバイリニア近似が 可能であり、設計用エネルギースペクトルにおける $V_{E O}$ は $\mathrm{h}=10 \%$ 減衰弾性 1 質点系の入力エネルギースペクト ルを包含するように設定される 。なお、 $T_{c}=T_{n} / 1.2$ 、 $T_{a}:$ 地震稹の卓越周期である。

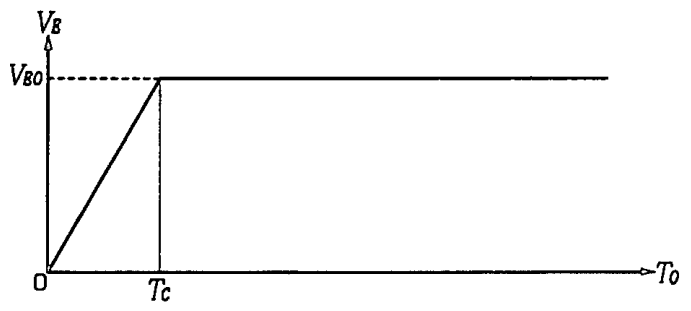

図ー11 設計用エネルギースペクトル

上記の重実を前提として、 $h=10 \% 、 T_{0} \geqq T_{c}$ の減衰線形 1 翼点系への任意の地震動による入力エネルギーの等価 速度換算值か $V_{E O}$ を上回る確率は極めて小さいと考える ことがでる。

定常ホワイトノイズによる入力エネルギーの確率分布 はガンマ分布となるが、 $\omega_{0} h T_{d}$ が大きくなると正規分布 に近つく2。これを参考にして地㤠動による入力エネル キ一の確率分布を正規分布と仮定すれば、入力エネルギ 一が次式によるエネルギー㹂を上回る確率は0.003 とな る。

$E_{\mathrm{a} A=0.1}=E\left[E_{I}\left(\omega_{0}\right)\right] \cdot\left(1+3 \cdot \operatorname{CV}\left[E_{I}\left(\omega_{0}\right)\right]_{A=0.1}\right)$

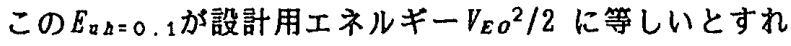
は、入力エネルギーの期待值は、

$$
E\left[E_{I}\left(\omega_{0}\right)\right]=\frac{V_{E O^{2}} / 2}{1+3 \cdot C V\left[E_{I}\left(\omega_{0}\right)\right]_{L=0.1}}
$$

変针係数として $(70)$ 式を用いれば、

$$
E\left[E_{I}\left(\omega_{0}\right)\right]=\frac{V_{E o^{2} / 2}}{1+3 / \sqrt{0.1 \omega_{\circ} T_{d}}}
$$

上式と $(56)$ 式を等監し、 $\pi S_{O} A=V_{E} O^{2} / 2$ とすると次の地 䅎特性フィルターの伝違関数が得られる。

$$
\left|F_{v}\left(\omega_{0}\right)\right|^{2}=\frac{1}{1+3 / \sqrt{0.1 \omega_{0} T_{d}}}
$$

上式は図ー11中の破線のように、エネルキースペクトル が短周期領域でも一定值 $V_{E O}$ をとるとしたときの伝達閣 数とみなせる。

田治見の伝達関数は次式で表され ${ }^{8)}$ 、

$$
\left|F_{T}\left(\omega_{\circ}\right)\right|^{2}=\frac{\omega_{g}^{4}+4 h_{g}^{2} \omega_{g}^{2} \omega_{o}^{2}}{\left(\omega_{0}^{2}-\omega_{g}^{2}\right)^{2}+4 h_{g}^{2} \omega_{g}^{2} \omega_{o}^{2}}
$$

$T_{s}=2 \pi / \omega_{s}=0.4 \mathrm{~s} 、 h_{s}=0.6$ とすれば Housnerの平均速 度応答スペクトル に合う。(74)式、(75)式の伝達関数 を図ー12に示した。 $T_{0}\left(=2 \pi / \omega_{0}\right)>T_{B}$ の領域ではいず れの伝達関数も $T_{0}$ の增加に伴って減少し、|FV $\left(\omega_{0}\right) \mid$ に 対する|F $F_{T}(\omega) \mid$ の比はほほ一定の值になる。これはエ ネルギースペクトルが $T_{0} \geqq T_{c}$ の領域では一定值をとるこ
とと対応している。すなわち、地留動によるエネルギー 入力を確幽的にとらえた場合、系の固有周期 $T$ 。が地盤の 卓越周期 $T_{g}$ を上回る領域では入力エネルギーの期待值は 地盤特性フィルターにより、T。の增加に伴いゆるやかに 娍少し、入力エネルキーの変動係数は逆に増加する。そ の結果、 $h=10 \%$ 系の入力エネルギーの最大値はほほー 定の值を示すと考えられる。

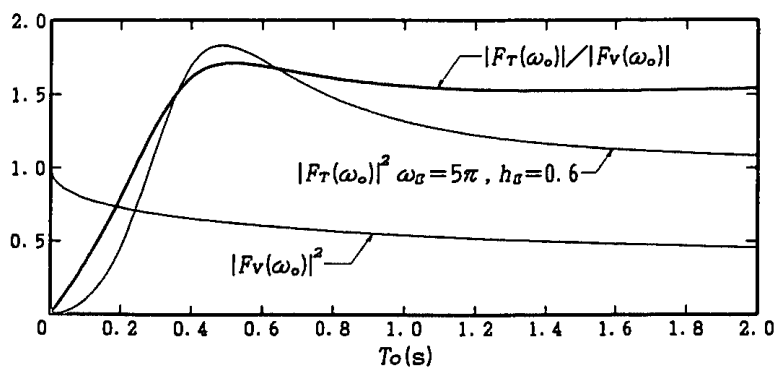

困ー12 地盤特性フィルターの伝達関数

\section{ه-7 地震動による履歷吸収エネルギー}

以上の考察に基づき、 $T_{d}=20 \mathrm{~s}$ の地震動による履歷吸 収エネルキー涟の上限を、定常ホワイトノイスに(61)式 の確定形状関败を乗じた擬定常ホワイトノイスによる履 歴吸収エネルギーの期待值 $E\left[E_{S}\right]$ として予測する。

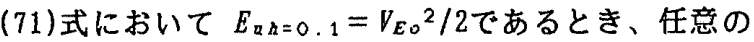
$h$ を有する系で同確率で期待できるエネルギー荲は次のよ うになる。

$$
E_{\mathrm{a} A}=\frac{1+3 \cdot \operatorname{CV}\left[E_{I}\left(\omega_{0}\right)\right]}{1+3 \cdot \operatorname{CV}\left[E_{I}\left(\omega_{0}\right)\right]_{h=0.1}} \cdot \frac{V_{\varepsilon O^{2}}}{2}
$$

$C V\left[E_{I}(\omega \circ)\right]$ として $(70)$ 式を用いれば、

$$
E_{\mathrm{a} h}=\frac{1+3 / \sqrt{h \omega_{0} T_{d}}}{1+3 / \sqrt{0.1 \omega_{\circ} T_{d}}} \cdot \frac{V_{E O^{2}}}{2}
$$

ガウス型ホワイトノイズのパワースペクトル密度S。は、 入力エネルギーの期待值 $\pi S_{0} T_{d} か ゙(77)$ 式の $E_{a_{a}}$ と等しく なるように次式により定める。

$$
S_{o}=\frac{1+3 / \sqrt{h_{r} \omega_{r} T_{d}}}{1+3 / \sqrt{0.1 \omega_{\circ} T_{d}}} \cdot \frac{V_{E 0}{ }^{2}}{2 \pi T_{d}}
$$

確定形状関数の係数 $b, c$ は(64)式、(65)式において $\mathbb{m}=6$ として、c=0.3,b=1.470とする。

このようにして設定される疑定常ホワイトノイスによ る倠䇥吸收エネルキーの期待值 $E\left[E_{s}\right]$ を 4-3項に示す手 法により求めるが、このとき、(78)式中に $h_{r} 、 \omega_{r}$ が含 まれているため次のような繰り返し計算を行う。(1)初期 值 $S_{o}=V_{E}{ }^{2} /\left(2 \pi T_{d}\right)$ として計算を行い、 $h_{r} 、 \omega_{r}$ を求め る。(2)得られた $h_{r} 、 \omega_{r}$ を(78)式に代入して $S_{0}$ を更新し、 再度計算を行い新たな $h_{r} 、 \omega_{r}$ を求める。以降、S。かi一 定の值に呮束するまで(2)繓り返す。実際に計算すると 3 回の絽り返しでS。は十分に呮束する。

本方法による予測值 $E\left[E_{S}\right]$ を地霞波によるシミュレー ション結界と比輘し、予測椬度を㛟証する。用いた地霞

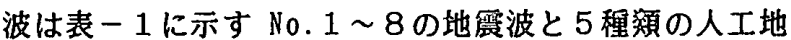


震波であり、これらの地震波は $h=10 \%$ 線形系における エネルキースペクトルの最大值が、第III種地盤における 設計用入力エネルギー $V_{E O}=200 \mathrm{kine}^{10)}$ となるように規

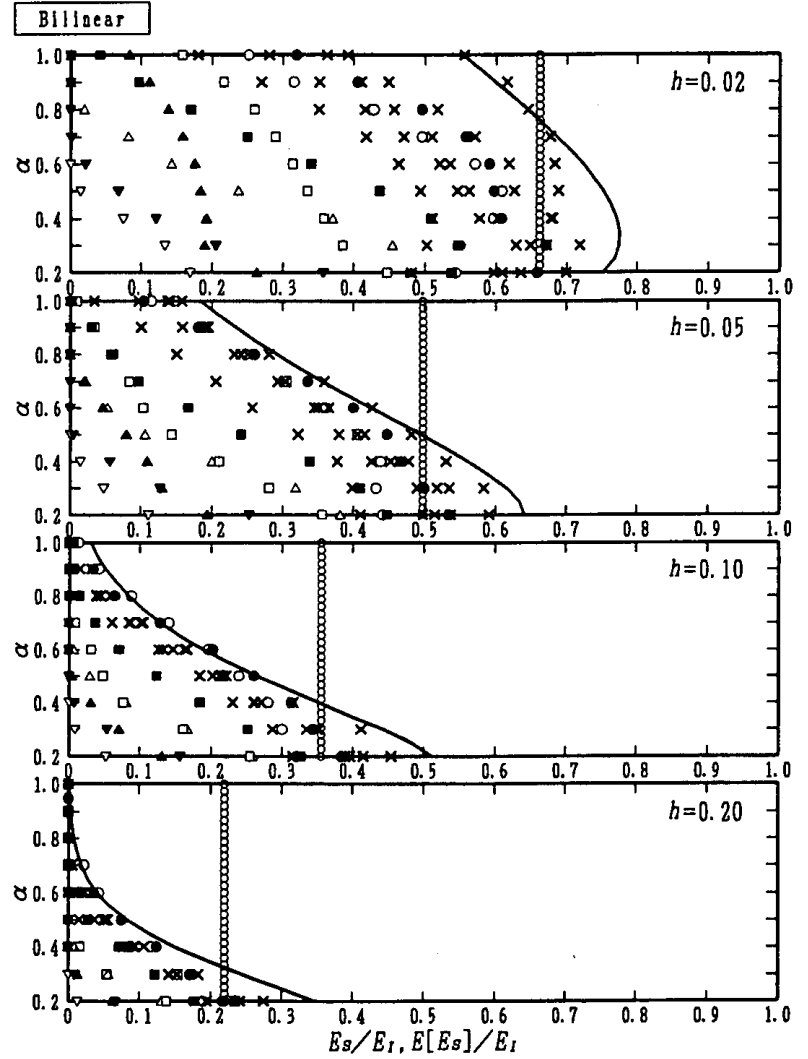

準化した。人工地震波は (74)式による伝達関数を用い、 図-4に示す方法で20波作成し、その中から系の固有周 期 $T$ 。近傍のエネルギースペクトルの大きなものを 5 波選

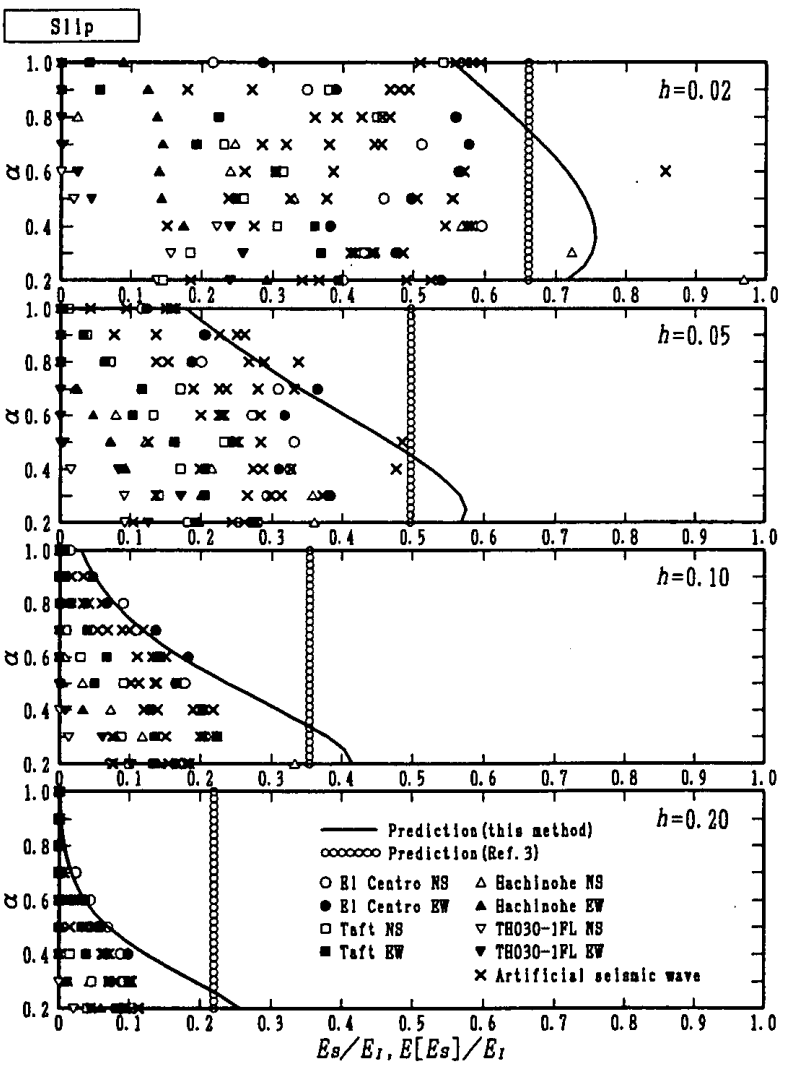

困 -13 地震波にる履歴吸収エネルギー、 $V_{E O}=200 \mathrm{kine} 、 T_{0}=0.5 \mathrm{~s}$
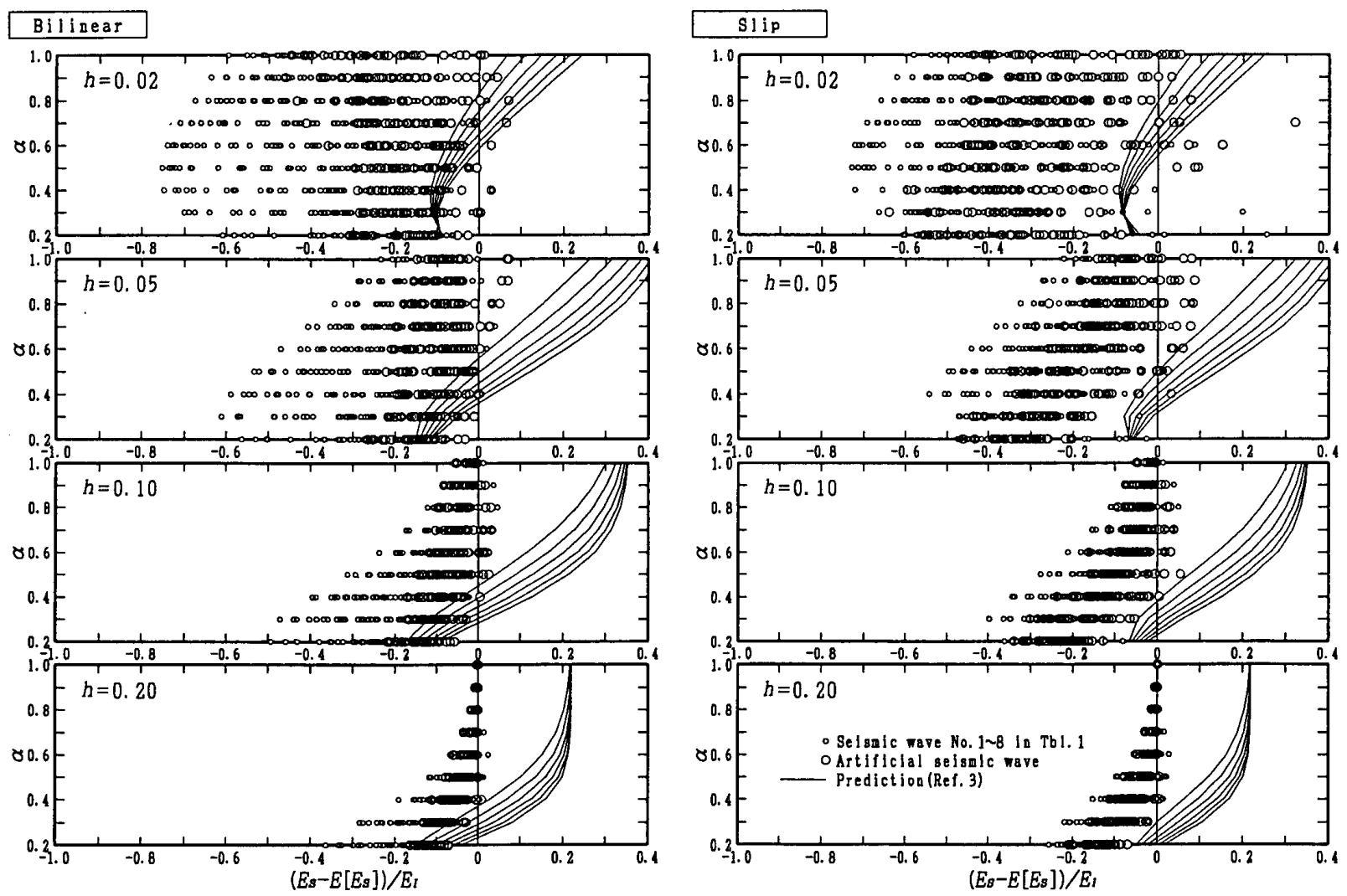

図ー14 地震波にる履歴吸収エネルギー、 $V_{E O}=200 \mathrm{kine} 、 T_{0}=0.5 \sim 0.9 \mathrm{~s}$ 


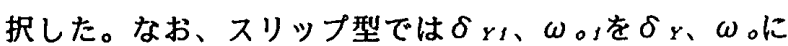
固定した疑似履歷モテルを用いた。

困ー13には $T_{0}=0.5 \mathrm{~s}$ の系における予測値 $E\left[E_{S}\right]$ とシミ ユレーション值 $E_{S}$ を示した。横帆は全入力エネルキー $E_{I}$ $=V_{E o}{ }^{2} / 2$ に対する比率で表示してある。予測值はほほシ ミュレーション值の上限をとらえているが、スリップ型 $h=0.02$ は他と異なり、数は少ないが予測值を大きく上 回る場合がある。図ー14には $T$ 。が0.4sから0.9sの系につ いて0.1s刻みで計算し、 $E\left[E_{s}\right]$ と $E_{S}$ 差 $E_{s}-E\left[E_{s}\right] の E_{I}$ に対する比率を重搳きした。本図においても予測值は ほほシミュレーション值の上限をとらえており、スリッ プ型, $h=0.02$ を除いて、 $E_{S} の E\left[E_{S}\right]$ に对する超過悬は $E_{I}$ の 1 别以下である。また、(1)式による予測值を併記し た。この予測值は概ねシミュレーション值の上限をとら えているが、 $\alpha 、 h$ が大きい場合は過大評価となる。

\section{5. 結語}

ランダム振動諭および既往の人工地霞波作成手法に基 づき、パイリニア型およびスリップ型の復元力特性を有

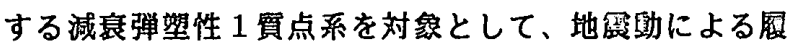
歷吸収エネルギーに関する㛟討を行った。結果は次のよ うに要約される。

1) 振動エネルキーが○で、入力エネルギーがすべて減 衰消琧され、応答の振幅がレーリ一分布に従うと仮定す ると、消筫エネルギーの時間率の期待値とその確率分布 は、履歷系の塑性化の度合いに無関係に定まる。また、 履噟系の応答振稫が降伏值に逹する降伏エネルギー入力 率は、復元力特性から定められ、塑性化に寄与するエネ ルギーの期待值 $E\left[E_{H}\right]$ およびその入力時間の期待値 $E\left[T_{H}\right]$ を、降伏エネルギー入力率を上回るエネルギー入力率お よび入力時間の期待值の累䅡值として求めることができ る。

2 ）入力がホワイトノイスの場合の履歷吸収ェネルキー の期待值を、上記の $E\left[E_{H}\right]$ およひ $E\left[T_{H}\right]$ を用いた最小自乗 法に基つく等価線形化手法により求めたが、既往の研究 結果 ${ }^{2}$ に較べ、 $\alpha 、 h$ の広い筑囲に渡りシミュレーショ ン值に一致することが確認できた。

3) ガウス型ホワイトノイスに確定形状関数を垂じた擬 定常ホワイトノイスによるエネルギー入力率の確率办布 は、確定形状関数を適当に選べば実地霞波のエネルキー 入力率の分布とほほ一致させることができる。また、実 地震波のエネルキー入力量の変動係数はガウス型ホワイ トノイスと同等とみなせる。

4 ）任意の地震波による入力エネルギーの最大值が、長 周期領域における設計用エネルギースペクトル $V_{E O}$ を上 回る確率が微小であることを条件として設定される地盤 特性フィルターの伝達関数と、一般の地毁波の地盤特性 を表す田治見の伝達関数 ${ }^{8)}$ の比は、長周期領域において
ほほ一定となる。このことから、設計用エネルギースペ クトルを長周期領域において一定とすることの妥当性が 確率論的に確認できる。

5）上記 3 ）、4）により、地震動によるエネルギー入 カの評価に関して、ガウス型ホワイトノイスに確定的な 形状関数と地盤特性フィルターを用いて得られる非定常 過程を地震動の確率モデルとすることができ、同モテル に基つくく履歷吸収エネルギーの予測值は、地震動による 履歴吸収エネルキー量の上限を概ねとらえることができ る。

地震動による履歴吸陨エネルギーの上限は（1)式によ っても大略上限を予測することができ、簡便である点で

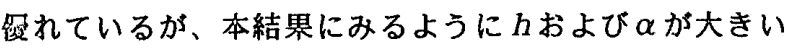
場合は過大評価となる。履歷吸収エネルギー晅は、ほほ hおよび $\alpha$ のに依存し、hが大きいほど $\alpha$ の影翌が大 きくなる。前述のように低層鉄骨建築物では非棈造部材 の耐震効界により建物全体の $h$ およひ $\alpha$ が増大する。こ のような建築物の主体榑造の地震時の損傷評価について 本手法は有効であると考える。

参驾文献

1) 三宅辰哉、福知保長：低層建築物における非榴造部材の 㑔霞伤界に関する研究 その 1 非相造部材による水平力 分担と減舞性の向上，日本建築学会极造系諭文報告急， 第 462 号, pp.151 160, 1994.8

2）浃起，田中 尚：ホワイトノイスを受ける1自由度系

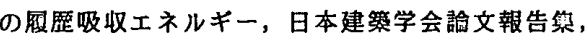
第 270 号, pp. $99 \sim 103$ ，昭和 53 年 8 月

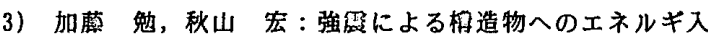

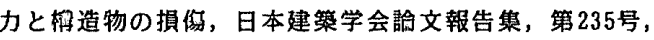
pp.9 18，昭和 50 年 9 月

4) 星谷 勝：確苹詥手法による振動解析，鹿島出版会， 昭和 49 年

5) 柴田明德：最新 的霞梅造解析，森北出版，1981

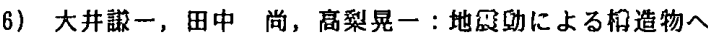
のエネルキー入力の統計目予测に関する基礎的考察，日 本建築学会相造系論文報告集，第347号，pp.47 55, 昭和 60 年 1 月

7) 秋山宏：建筑物の耐级检限設計, 菓京大学出版会, 1980.9

8）田治見宏：建築振動学，コロナ社，昭和40年

9) G.H.Housner:behavior of Structures during Earthquake, Proceedings, ASCE, EM4, Oct.1959

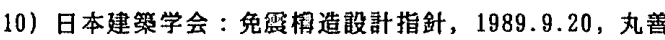

（1994年10月 7 日原稿受理，1995年 1 月20日拯用決定） 